in stored grains have also been investigated. Fisheries investigations have covered smoking of fish, fish liver oil production, and investigations on Australian tunas, pilchards, mullets, etc.

Brief reference is made to the work of the National Standards Laboratory, to aeronautical investigations at the Aeronautical Laboratory, which has now been given the status of a Division, and to investigations in industrial chemistry, including that on unshrinkable wool, on wool wax, utilization of minerals and on producer gas investigations, particularly the suitability of Australian hardwoods for the production of charcoal. Substantial progress has been made in building up a research organization and the development of research methods for dealing with lubrication, bearing and wear problems in Australia. The work is undertaken as co-operative research with the University of Melbourne and housed in the new chemistry school. The work of the Dairy Research Section has included a survey of the properties of Australian butter and the storage and transport of butter fat without refrigeration.

\section{NORTH SYRIAN ARCHAOLOGY AND OLD TESTAMENT SOURCES}

$\mathrm{T}$

HE July-August number of Man contains, among other interesting matter, a résumé of the most recent results obtained by Commander Schaeffer at his Ras Shamra dig. North Syria was a very important area geographically in prehistoric times, and the excavations at Ras Shamra, like those of Mersin in Cilicia, alas scarcely more than begun, may well prove to be some of the most interesting in the Near East.

The early story of Ras Shamra goes back into Neolithic times, and a peculiar dark, incised pottery has been found in the lowest level, which, at Mersin, occurs in a definitely Neolithic milieu associated with a splendid industry made in obsidian. But at a later date Ras Shamra was a Bronze Age Canaanite town of considerable importance and the capital of the kingdom of Ugarit, well known in Egypt, Baby lonia and the Hittite empire. It was a meoting-place of Minoan, Mycenean, Babylonian and Anatolian cultures. Cuneiform texts have been unearthed which reveal the Canaanite mythology and were at any rate one of the sources drawn upon by the writers of the Old Testament.

he last $(1938-39)$ of the ten seasons of pre-war $k$ has considerably strengthened our knowledge his respect, having enabled certain documents to accurately dated; and it would now seem that ty of the Patriarchal stories of the Old Testament $\mathrm{H}_{\mathrm{g}}$ not mere oral tradition collected by authors of time of Solomon and later, but were part of a itten heritage derived from the Canaanite Bronze a. Furthermore, it would appear that some of 10 religious and moral progress achieved farther ?th. -y the great Old Testament prophets had already started some centuries earlier in the mothercivilization of that Israelite culture which has meant so much to the world.

The latest work also unearthed the royal palacefortress, which was protected by square towers of massive stone-work and in which were found the royal archives. The contents of the palace as a whole were very interesting and included a fine gold encrusted battle-axe with an iron blade belonging to the end of the fifteenth century B.C., as well as the muster roll of the army of Ugarit, naming the oificers and men and the number of bows and slings handed over to them. The tale of dismantling, restoration and final destruction which the excavations unfold seems to show that this kingdom of Ugarit with its capital of Ras Shamra finally went under at the beginning of the twelfth century B.C. to those same northern sea-borne invaders who effected the ruin of Troy. All this new information we owe to Ras Shamra and the latoours of Commander Schaeffer and his archæological and literary helpers.

M. C. Burkitt.

\section{FEEDING AND BREEDING OF CALANUS FINMARCHICUS}

$T$ HE importance of Calanus finmarchicus in the economics of the sea is so great that more attention has been paid to it than to any other copepod. That Dr. F. Gross and Mr. J. E. G. Raymont are now able to keep the adults for months under controlled conditions is a very definite advance on former work, and the two papers now before us are full of interest and suggestive observations ${ }^{1}$.

Dr. Gross ${ }^{2}$, in previous experiments, had made successful persistent cultures of many diatoms, using "Erdschreiber" as medium (a combination of nitrates, phosphates and soil extract) and had specialized in extending the method to minute flagellates. The present work on Calanus depends on its feeding on these cultures-both diatoms and flagellates-and its main importance lies in the fact that such food is found to be sufficient for the adults during their normal life-time. It is shown conclusively that for long periods Calanus can live entirely on a diatom diet, or one of diatoms and flagellates together, provided that there is a large amount of the food present, much more than under natural conditions in the sea. For a shorter period, they can live on flagellates alone. Nicholls ${ }^{3}$, from field data, placed the life of an adult female at about six weeks. In Raymont's and Gross's large cultures of females, more than half the animals generally remained healthy for three to nine weeks, while a few were kept active for more than a hundred days. The maximum number of adult animals which could live successfully in 200 c.c. Erdschreiber medium, with excess of food and weekly change of medium, was approximately twenty. Adult males did not live so long as the females, and this is probably what takes place in Nature, as has already been suggested by Ruud ${ }^{4}$. The present experiments show that the females feed more actively than the males, the number of freal pellets being more than 2-10 times as great and the size of the pellets of the females greatly exceeding those of the males. The moulting of Stage $\mathrm{V}$ was found to be a critical stage when many specimens died.

The diatoms used included large and small species, the large Ditylium being specially useful. That Calanus finmarchicus is a mixed feoder in its natural surroundings is well known, and it has been shown by Lebour ${ }^{5}$ and Marshall ${ }^{6}$ that Crustacea remains are sometimes to be found in the gut contents. Marshall states that "a certain proportion of Calanus are always found eating crustaceans" She found that 7-48 per cent of the guts examined contained Crustacea, according to the season, and they were usually taken 